\title{
Wild Rabbit Exposure to Leishmania infantum, Toxoplasma gondii, Anaplasma phagocytophilum and Babesia caballi Evidenced by Serum and Aqueous Humor Antibody Detection
}

\author{
Labrini V. Athanasiou ${ }^{1} * \mathbb{D}^{\mathbb{D}}$, Eleni G. Katsogiannou ${ }^{1}\left(\mathbb{D}\right.$, Constantina N. Tsokana ${ }^{1} \mathbb{D}$, Sofia G. Boutsini ${ }^{2}$, \\ Marina G. Bisia ${ }^{1}$ and Vasileios G. Papatsiros ${ }^{1}$ D \\ 1 Department of Medicine, Faculty of Veterinary Medicine, University of Thessaly, 43100 Karditsa, Greece; \\ elkatsog@uth.gr (E.G.K.); kotsokan@vet.uth.gr (C.N.T.); mbisia@outlook.com (M.G.B.); \\ vpapatsiros@vet.uth.gr (V.G.P.) \\ 2 Veterinary Centre of Athens, General Directorate of Veterinary Services, Parasitology_Parasitic Diseases, \\ Entomology and Bee Health Department, 15341 Athens, Greece; sboutsini@yahoo.gr \\ * Correspondence: lathan@vet.uth.gr; Tel.: +30-244-106-6009; Fax: +30-244-106-6053
}

Citation: Athanasiou, L.V.; Katsogiannou, E.G.; Tsokana, C.N.; Boutsini, S.G.; Bisia, M.G.; Papatsiros, V.G. Wild Rabbit Exposure to Leishmania infantum, Toxoplasma gondii, Anaplasma phagocytophilum and Babesia caballi Evidenced by Serum and Aqueous Humor Antibody Detection. Microorganisms 2021, 9 , 2616. https://doi.org/10.3390/ microorganisms 9122616

Academic Editor: Pat Nuttall

Received: 13 November 2021 Accepted: 14 December 2021 Published: 17 December 2021

Publisher's Note: MDPI stays neutral with regard to jurisdictional claims in published maps and institutional affiliations.

Copyright: (c) 2021 by the authors. Licensee MDPI, Basel, Switzerland. This article is an open access article distributed under the terms and conditions of the Creative Commons Attribution (CC BY) license (https:// creativecommons.org/licenses/by/ $4.0 /)$.

\begin{abstract}
Wild rabbits (Oryctolagus cuniculus) can be important sentinel species for the presence of zoonotic pathogens. Therefore, we collected blood samples from wild rabbits harvested by hunters during the hunting season 2019-2020 on the island of Lemnos, to determine exposure of wild rabbits to the zoonotic pathogens Leishmania infantum, Toxoplasma gondii, Anaplasma phagocytophilum and Babesia caballi, as well as aqueous humor to assess its diagnostic performance in terms of sensitivity, specificity, positive and negative likelihood ratios. Antibodies against these pathogens were detected by Indirect Immunofluorescence Antibody (IFA) assay. Out of the 72 wild rabbits included in the study, $4.2 \%, 5.5 \%, 18 \%$ and $9.7 \%$ were seropositive to L. infantum, T. gondii, A. phagocytophilum and B. caballi, respectively. Although less frequently, antibodies were also detected in aqueous humor of wild rabbits. The antibody detection in aqueous humor presented $100 \%$ specificity but decreased sensitivity compared to serum suggesting that aqueous humor could be successfully used in epidemiological studies to confirm exposure at the population level but has little diagnostic value at the individual level. This is the first report on the seropositivity of wild rabbits to A. phagocytophilum and B. caballi and the detection of antibodies against A. phagocytopylum, L. infantum, T. gondii and B. caballi in the aqueous humor.
\end{abstract}

Keywords: aqueous humor; A. phagocytophilum; B. caballi; L. infantum; T. gondii; antibodies; Indirect Immunofluorescence Antibody Assay; serology; wild rabbits

\section{Introduction}

Oryctolagus cuniculus is one of the most widespread lagomorph species occupying a huge variety of ecosystems. Their intermediate size and great abundance allows them to support a community of small to medium-sized predators such as foxes, cats and civets with which they share the same habitats. This species occurs in both wild and domestic forms. Its domestic counterpart is raised globally for meat, wool and fur, and it is also an increasingly popular pet [1]. Besides, they are considered to be a useful sentinel species for the level of environmental contamination and the circulation of pathogens in their habitat [2,3].

Leishmaniosis caused by the protozoan Leishmania infantum is a severe vector-borne zoonotic disease that is endemic in the Mediterranean basin [4]. Transmission occurs via the bite of female sand flies of the subfamily Phlebotominae. L. infantum is the causative agent of zoonotic visceral (VL) and cutaneous leishmaniosis (CL) in humans, and of canine leishmaniosis in dogs, the main reservoir host of the parasite [5]. The existence of a sylvatic L. infantum transmission cycle in wildlife that overlaps with the domestic cycle 
maintained by dogs has been well documented as one of the main factors limiting disease control [6,7]. The outbreak of human leishmaniosis in southern Madrid involving Iberian hares (Lepus granatensis) and wild rabbits (O. cuniculus) $[7,8]$ as well as the following studies in Lepus europaeus in different European countries including Greece [9-11] showed how anthropogenic interventions in ecosystems that lead to high density of some wild species, and increased contact with domestic animals and humans, could dramatically affect the epidemiology of a disease [12,13]. Importantly, rabbit infectiousness to P. perniciosus sand flies has been demonstrated by xenodiagnosis suggesting the competence of this species as a host reservoir [8].

Toxoplasma gondii, a protozoan parasite with global distribution, can infect virtually every warm-blooded animal, including humans and livestock which act as intermediate hosts. Domestic and wild felids are the definitive hosts, being able to excrete oocysts to the environment. Humans commonly get infected through consumption of undercooked or raw meat containing tissue cysts [14]. However, ingestion of oocysts directly from the environment, indirectly via contaminated food or drinking water or while field dressing game by hunters, can also lead to infection [14,15]. As for the lagomorphs, they are mainly infected with T. gondii via the ingestion of water and plants contaminated with oocysts excreted by felids with which they share the same habitats [16]. Thereafter, infected lagomorphs can act as a potential source of $T$. gondii for other animals, especially for their predators, but also for humans [16,17].

Concerning the Anaplasma species, obligate rickettsial pathogens, that are mainly transmitted by different species of hard ticks and proliferate inside red blood cells, cause clinical and subclinical infections in a variety of vertebrate hosts. To the authors' knowledge, there are no data available in the literature on the Anaplasma spp infection/exposure status of $O$. cuniculi. However, there is increasing evidence of $A$. phagocytophilum infection/exposure in several wild rabbit species including Le. europaeus in Italy [18], cottontail rabbits (Sylvilagus floridanus) in Massachusetts [19,20], Lepus sinensis in China [21] and riparian brush rabbits (Sylvilagus bachmani riparius) in California [22].

Babesiosis is a vector-borne disease caused by erythrocytic protozoal parasites of the genus Babesia. These piroplasms are of medical and veterinary importance worldwide and can cause severe disease in humans, domestic animals and wildlife [23,24]. Transmission of Babesia spp. mainly occurs through the bite of infected ixodid ticks [25]. In Europe, $B$. divergens remains the most frequent cause of human babesiosis, while in North America, $B$. microti is the most reported species associated with human disease. Other zoonotic species that have been reported are B. duncani and B. venatorum [26,27]. B. caballi is the aetiological agent of equine piroplasmosis, a tick-borne disease, which is characterized by persistent infection and carriers act as sources of infection for ticks [28,29].

Blood sampling can be challenging in the context of seroepidemiological studies in wild animals [30]. Regarding carcasses, blood collection through right heart puncture may not be successful due to post mortem blood clotting. In recently deceased animals whose blood has not yet clot, further handling is needed after blood is drawn. Blood samples should be centrifuged or left undisturbed for approximately $30 \mathrm{~min}$ to encourage clot formation [31,32]. Besides, it has been suggested that after death, blood rapidly deteriorates due to post mortem blood clotting, contamination by bacteria, release of intracellular chemicals and metabolism of serum compounds [32]. Thus, the collection of samples alternative to blood and serum, like blood on filter papers or aqueous humor, have been evaluated in terms of their diagnostic accuracy in different animal species and for several pathogens [30,33-39].

Aqueous humor is an eye-specific sample, easy to obtain, with good stability and minimally invasive compared to other types of eye specimens [40-42]. Recently, it has gained attention as an alternative biological sample that could assist in the diagnosis of several infectious and neoplastic ocular diseases in human and animal medicine. Thus, a number of studies used serologic, molecular and immunocytochemical assays as well as 
cytologic examination to define the diagnostic efficiency of aqueous humor in dogs, cats and rabbits [37,43-45].

The diagnostic utility of aqueous humor for the detection of antibodies in rabbits has been previously investigated only for anti- Toxocara canis and anti- T. gondii IgG following experimental infection $[33,38]$. To the authors' knowledge, there are no data available coming from field studies in naturally infected rabbits. Moreover, data on the exposure rate of wild rabbits in Greece to pathogens with zoonotic potential, is limited to one study concerning L. infantum infection [46]. This is especially important for the wild rabbit population in the island of Lemnos, northern part of the Aegean Sea, Greece, where since 1995, wild rabbits, due to overpopulation, have significantly disrupted the ecosystem, causing huge losses and extensive damage to crops. Significant effort has been made by the state authorities for the management of rabbit population in the island [47-49]. Thus, the objectives of this study were (a) to provide evidence on the occurrence of wild rabbit exposure to L. infantum, T. gondii, A. phagocytopylum and B. caballi in the island of Lemnos, northern part of the Aegean Sea, Greece (b) to assess the diagnostic utility of aqueous humor for the detection and quantification of $\operatorname{IgG}$ antibody levels against the above-mentioned pathogens compared to serum samples in naturally infected wild rabbits.

\section{Materials and Methods}

\subsection{Animals}

The samples included in this study were collected from 72 wild rabbits from the island of Lemnos (Longitude: $25^{\circ} 11^{\prime} 45.38^{\prime \prime} \mathrm{E}$, Latitude: $39^{\circ} 56^{\prime} 35.77^{\prime \prime} \mathrm{N}$ ) which were hunter harvested during the hunting season 2019-2020 according to the prerequisites of the Greek Legislation (Hellenic Government Gazette 3137/6-8-2019, issue B) [50]. The island of Lemnos is located in the northern part of the Aegean Sea covers an area of 477.583 square kilometers, has Mediterranean climate and strong winds. The authors declare that no animals were killed for the purpose of this study and that all procedures contributing to this work met the ethical standards of the relevant national and European regulations on the care and use of animals (Directive 2010/63/EC).

\subsection{Sampling}

Paired blood and aqueous humor samples were collected within three hours from the death of animals. More specifically, blood samples were collected from the heart, transferred into sterilized containers and an average of $0.3 \mathrm{~mL}$ of aqueous humor was collected with gently aspiration from both eyes using a syringe with a $21 \mathrm{G}$ needle, which was inserted horizontally just under the cornea into the anterior chamber. The aqueous humor and blood samples were transferred to the laboratory. Blood samples were centrifuged at $400 \times g$ for $10 \mathrm{~min}$ for serum recovery. All samples were stored at $-20^{\circ} \mathrm{C}$ pending analysis.

\subsection{Indirect Immunofluorescence Antibody (IFA) Assay}

All the serum and aqueous humor samples were tested, by indirect fluorescence antibody test (IFAT), for the presence of the antibodies against L. infantum, T. gondii, A. phagocytophilum and B. caballi using different commercial agent specific slides (Fluoleish, Biovetotest Diagnostic Veterinaire, France, Fuller Laboratories Fullerton, California, USA, MegaFLUO ${ }^{\circledR}$ ANAPLASMA ph. Horbranz, Austria and Agrolabo, Scarmagno, Italy, for L. infantum, T. gondii, A. phagocytophilum and B. caballi, respectively). For all IFATs, a fluorescein isothiocyanate conjugated anti-rabbit IgG (Sigma-Aldrich, St Luis, MO, USA) was used.

For the detection of antibodies, in both serum and aqueous humor, against L. infantum, T. gondii and A. phagocytophilum, a dilution of 1:25 was used as cut off value, while the threshold value for the detection of antibodies against Babesia spp. was 1:50, as previously reported [22,51-53]. Moreover, a cut off value of 1:10 was used in aqueous humor, for the detection of antibodies against all the above-mentioned microorganisms. A Nikon Eclipse E-400 fluorescence microscope was used for the observation (objective $\times 100$ ). 


\subsection{Data Analysis}

For the statistical analysis of the data, MedCalc Statistical Software v.14.8.1 (MedCalc Software bvba, Ostend, Belgium; http:/ / www.medcalc.org; 2014, accessed on 10 November 2021) was used in order to calculate the sensitivity, the specificity, Positive likelihood ratio (PLR) and Negative likelihood ratio (NLR). PLR values $>10$ and NLR values $<0.1$ are indicative of good test performance [54]. Moreover, the agreement between the results of the tests performed in the two different biological samples was measured using the Cohen's Kappa ( $\mathrm{K}$ ) value. A value of 0 indicates fair agreement, while a value of 1 indicates a perfect agreement $[55,56]$. A value of $p \leq 0.05$ was considered significant in all comparisons.

\section{Results}

Out of the 72 serum samples tested, three $(4.2 \%)$ were positive against $L$. infantum, four (5.5\%) against T. gondii, 13 (18\%) against $A$. phagocytophilum and seven (9.7\%) against $B$. caballi (Figure 1). Employing the same cut off values in aqueous humor examination, resulted in fewer positive samples; one (1.3\%) for the detection of antibodies against $L$. infantum and T. gondii, four (5.5\%) and two (2.7\%) against A. phagocytophilum and B. caballi, respectively. When the cut off value of 1:10 was selected, equal number of positive samples was obtained for L. infantum and T. gondii and higher for the other two microorganisms (6 and 3 , respectively) (Table 1 ).

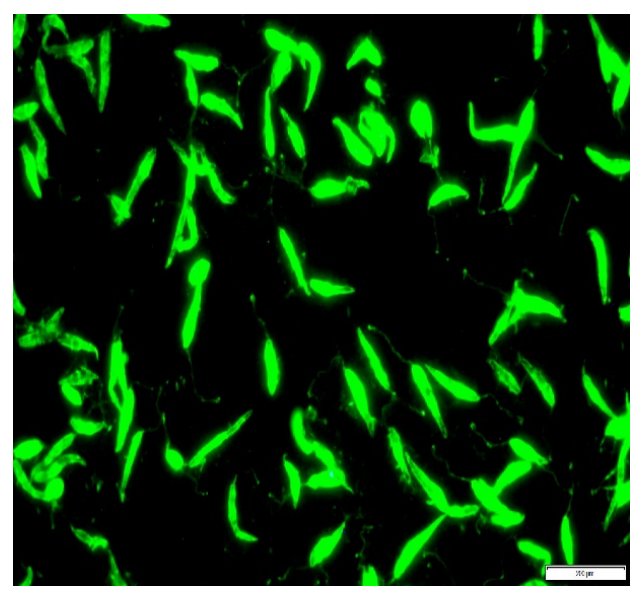

(a)

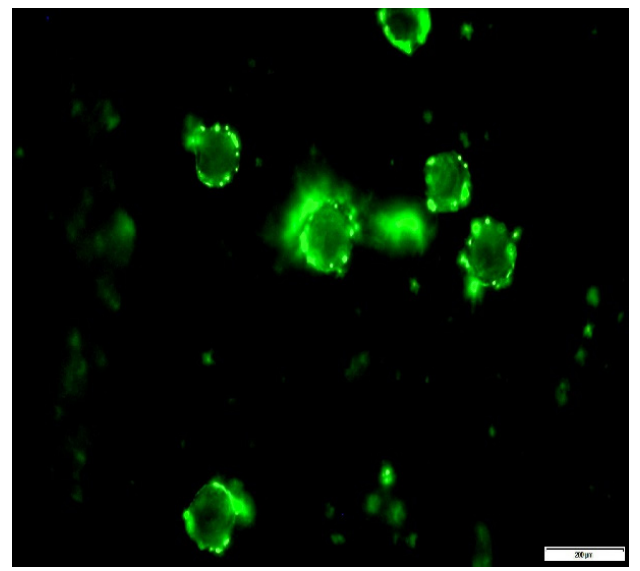

(c)

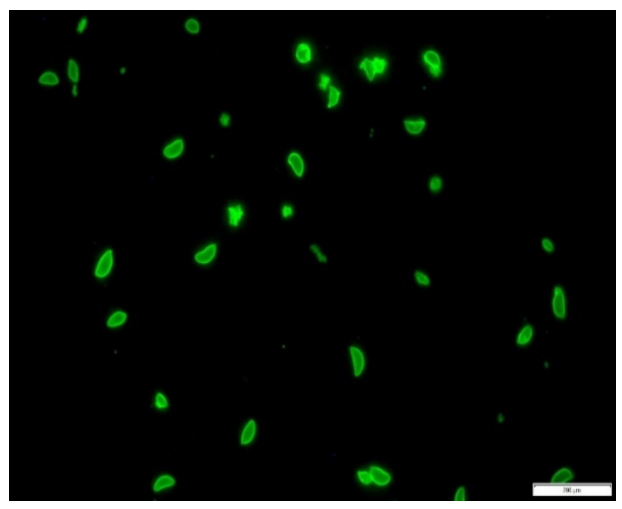

(b)

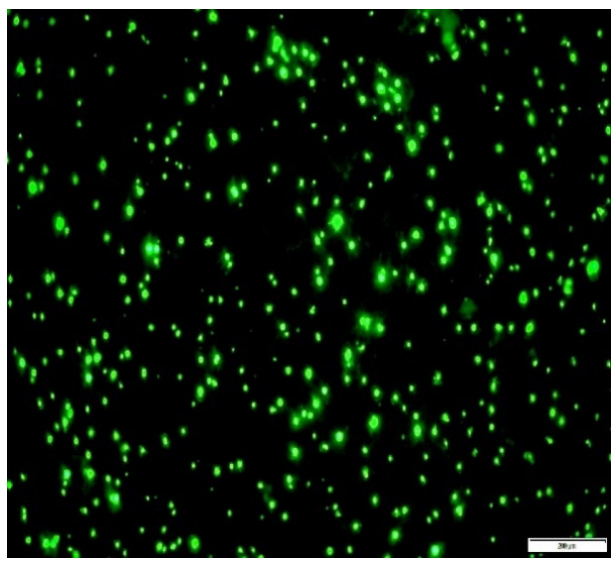

(d)

Figure 1. Image of Indirect Immunofluorescence Antibody (IFA) assay observed by a Nikon Eclipse fluorescence microscope (objective $\times 100$ ). (a) L. infantum positive IgG antibody reaction, serum titer 1:25; (b) T. gondii positive IgG antibody reaction, serum titer 1:25, (c) A. phagocytophilum positive IgG antibody reaction, serum titer 1:25 and (d) B. caballi positive IgG antibody reaction, serum titer 1:50. 
Table 1. Number and percentage of positive samples for antibodies against L. infantum, T. gondii, A. phagocytophilum and B. caballi in wild rabbits, in serum and in aqueous humor, with the same cut off value (1:25 or 1:50) and with a lower cut off value (1:10) in aqueous humor.

\begin{tabular}{|c|c|c|c|c|c|c|}
\hline & \multicolumn{3}{|c|}{ Serum } & \multicolumn{3}{|c|}{ Aqueous Humor } \\
\hline & \multirow{2}{*}{ Cut Off Value } & \multicolumn{2}{|c|}{ Positive } & \multirow{2}{*}{ Cut Off Value } & \multicolumn{2}{|c|}{ Positive } \\
\hline & & $\mathbf{N}$ & $\%$ & & $\mathbf{N}$ & $\%$ \\
\hline \multirow{2}{*}{ L. infantum } & \multirow{2}{*}{$1: 25$} & \multirow{2}{*}{3} & \multirow{2}{*}{4.2} & $1: 25$ & 1 & 1.3 \\
\hline & & & & $1: 10$ & 1 & 1.3 \\
\hline \multirow{2}{*}{ T. gondii } & \multirow{2}{*}{$1: 25$} & \multirow{2}{*}{4} & \multirow{2}{*}{5.5} & $1: 25$ & 1 & 1.3 \\
\hline & & & & $1: 10$ & 1 & 1.3 \\
\hline \multirow{2}{*}{ A. phagocytophilum } & \multirow{2}{*}{$1: 25$} & \multirow{2}{*}{13} & \multirow{2}{*}{18} & $1: 25$ & 4 & 5.5 \\
\hline & & & & $1: 10$ & 6 & 8.3 \\
\hline \multirow{2}{*}{ B. caballi } & \multirow{2}{*}{$1: 50$} & \multirow{2}{*}{7} & \multirow{2}{*}{9.7} & $1: 50$ & 2 & 2.7 \\
\hline & & & & $1: 10$ & 3 & 4.2 \\
\hline
\end{tabular}

N: number of positive samples, $\%: \%$ positive samples.

The results of antibody detection against L. infantum, T. gondii, A. phagocytophilum and B. caballi in wild rabbits, in serum and in aqueous humor at individual level using different cut-off points are presented in the Supplementary Table S1.

The agreement between the serum and the aqueous humor samples examination, as it is shown by the Cohen's Kappa ( $\mathrm{k}$ ) values, was low when the same cut off value was used (1:25 or 1:50) for both types of samples. However, in the case of A. phagocytophilum and $B$. caballi, a better agreement was achieved when a cut off value of 1:10 was used for the aqueous humor (Table 2 ). This improvement in $k$ values was probably evident only for these two pathogens due to the higher number of positive samples detected.

Table 2. Agreement between serum and aqueous humor of wild rabbits for the detection of antibodies against L. infantum, T. gondii, A. phagocytophilum and B. caballi.

\begin{tabular}{ccc}
\hline & S-AH1 & S-AH2 \\
\hline L. infantum & 0.489 & 0.489 \\
T. gondii & 0.386 & 0.386 \\
A. phagocytophilum & 0.421 & 0.584 \\
B. caballi & 0.419 & 0.575
\end{tabular}

S: serum, AH1: aqueous humor with the same cut off value with the serum, AH2: aqueous humor with a cut off value of 1:10.

As for the diagnostic accuracy of antibody detection in aqueous humor compared to serum, which was used as the reference standard, the sensitivity, specificity, positive and negative likelihood ratios were calculated and they are presented in Tables 3 and 4, for the same with serum and the 1:10 cut off values, respectively. More specifically, the highest sensitivity was observed for anti-L.infantum antibodies when the cut-off value applied was 1:10 (60\%). The specificity was almost perfect in all cases regardless of the cut-off value used. PLR values showed good performance in all cases while the best NLR value (lower) was observed for anti-L.infantum antibodies when the cut-off value applied was 1:10. 
Table 3. Sensitivity, specificity and negative likelihood ratio (NLR) of aqueous humor, when cut off values are the same with those that used for the serum.

\begin{tabular}{ccccc}
\hline & L. infantum & T. gondii & A. phagocytophilum & B. caballi \\
\hline Sensitivity (\%) & 33.33 & 25.00 & 30.77 & 28.57 \\
95\% CI & $0.84-90.57$ & $0.63-80.59$ & $9.09-61.43$ & $3.67-70.96$ \\
Specificity (\%) & 100.00 & 100.00 & 100.00 & 100.00 \\
95\% CI & $94.79-100.00$ & $94.72-100.00$ & $93.94-100.00$ & $94.48-100.00$ \\
PLR & - & - & - & - \\
95\% CI & - & 0.75 & 0.69 & - \\
NLR & 0.67 & $0.43-1.32$ & $0.48-0.99$ & 0.71 \\
95\% CI & $0.30-1.48$ & . & -1.14 & \\
\hline
\end{tabular}

PLR: positive likelihood ratio, NLR: negative likelihood ratio, CI: confidence interval.

Table 4. Sensitivity, specificity, positive likelihood ratio (PLR) and negative likelihood ratio (NLR) of aqueous humor, when cut off value is 1:10.

\begin{tabular}{ccccc}
\hline & L. infantum & T. gondii & A. phagocytophilum & B. caballi \\
\hline Sensitivity (\%) & 60.00 & 25.00 & 38.46 & 28.57 \\
95\% CI & $14.66-94.73$ & $0.63-80.59$ & $13.86-68.42$ & $3.67-70.96$ \\
Specificity (\%) & 100.00 & 100.00 & 98.31 & 98.46 \\
95\% CI & $94.79-100.00$ & $94.72-100.00$ & $90.91-99.96$ & $91.72-99.96$ \\
PLR & - & - & 22.69 & 18.57 \\
95\% CI & - & - & $2.89-178.29$ & $1.92-179.82$ \\
NLR & 0.40 & 0.75 & 0.63 & 0.73 \\
95\% CI & $0.14-1.17$ & $0.43-1.32$ & $0.41-0.96$ & $0.45-1.16$ \\
\hline
\end{tabular}

PLR: positive likelihood ratio, NLR: negative likelihood ratio, CI: confidence interval.

\section{Discussion}

Wild rabbits are important small game animals extensively hunted in many countries. Rabbit meat is considered one of the most nutritional white meats and the demand for human consumption of rabbit meat is increasing. Apart from its economic significance, domestic rabbits are also scientifically important as key laboratory animals in medical research. On the other hand, rabbits are pests of national significance in several geographical areas $[1,57]$. These aspects together with the abundance of wild rabbits and their close proximity to humans and domestic animals have resulted in increasing scientific interest and research, including the occurrence of pathogens with zoonotic potential in rabbit populations globally.

In the present study, wild rabbit samples were screened for the presence of antibodies against $L$. infantum, a zoonotic disease steadily endemic in canine population in Greece [58,59]. Serological data in wild rabbits in Greece come from a previous study conducted in a wild rabbit population in the island of Lemnos and domestic rabbits from three Regional Units of Central Macedonia (Thessaloniki, Chalkidiki, Serres). This study showed an overall seroprevalence of $7.6 \%$ in domestic and wild rabbits [46]. A low percentage of seropositivity was observed in the wild rabbit population however, in agreement to the results of the present study. Similarly, serological studies in wild rabbits showed a variance of $0-75.4 \%$ leading to controversial conclusions on the possible role of rabbits in the epidemiology of leishmaniosis [46,51,60-62]. A recent study confirmed that natural Leishmania infection in wild rabbits is not associated to gross pathology and only minimal histopathological lesions were observed while L. infantum antigens were most frequently detected in skin $[51,63]$. Previous studies showed that L. infantum is widely spread in wild rabbit populations with infection prevalence ranging from $0 \%$ to $100 \%[2,46,51,60,61,64-66]$. Highly heterogeneous prevalence values were recently reported even in different municipalities in Spain, suggesting that apart from the intrinsic restrictions of the methods applied and the samples selected for examination, Leishmania infection is clustering in space and time in local scale [2]. When optimal circumstances exist in terms of co-existence and close 
proximity of competent host reservoirs and vectors in a geographical area, the sylvatic and domestic transmission cycle of L. infantum may overlap [6].

Different species of warm-blooded mammals, birds, as well as human [14,67] comprise the wide range of hosts that have been found exposed to T.gondii. Several studies have shown the occurrence of antibodies against T.gondii in rabbits, mainly the European rabbit (O. cuniculus) with seroprevalences ranging from $0.9 \%$ to $37.5 \%[17,68,69]$. In wild rabbits, low seroprevalences of 3.3\% in Scotland [70] and 2.8\% in Portugal [71] were reported while a study in Australia showed that the mean seroprevalence was 9.9\% [3] and in Spain a seroprevalence as high as $53.8 \%$ was previously recorded [52]. Compared to the abovementioned studies, the seropositivity of $5.5 \%$ detected in the present study, is considered as quite low. High prevalence of infection has been reported in Portugal (67.9\%) [72] and Mexico (68.4\%) [73]. Infections in rabbits are mainly subclinical [16,70]. However, viable $T$. gondii could still be present in the tissues of seropositive lagomorphs posing a threat for hunters while handling apparently healthy individuals in the field [70].

This is the first report, to the authors' best knowledge, regarding the presence of antibodies against $A$. phagocytophilum and $B$. caballi in wild rabbits, although, antibodies against these tick-borne pathogens have been identified in other hosts. As for A. phagocytophilum, the pathogen has been found in humans [74] and in certain animal species [75,76], in Greece. However, recently in a laboratory study aiming to assess the vector competence of Rhipicephalus sanguineus for Anaplasma platys, previously naïve New Zealand white rabbits, which are not known to be susceptible to A. platys infection, produced IgG antibodies detectable in IFAT [77]. Moreover, increasing evidence of Anaplasma infection in lagomorphs exists, with $A$. phagocytophilum being the most frequently reported in other wild rabbit species with seroprevalence ranging from $0.9 \%$ in Le. europaeus in Italy [18] to $66 \%$ in cottontail rabbits (Sylvilagus floridanus) in Massachusetts $[19,20]$ and DNA prevalence ranging from $1.86 \%$ in Le. sinensis in China [21] to $29 \%$ in riparian brush rabbits (Sylvilagus bachmani riparius) in California [22]. No evidence of obvious infection has been recorded so far while it has been suggested that wild rabbits may act as maintenance hosts. However, this hypothesis needs further elucidation. Public health concern is raised in this case due to the occurrence of infected wild rabbits in close proximity to humans and on the propensity of the involved ticks to attach and feed on humans and other vertebrate hosts [78].

To the authors' best knowledge, there is no evidence of Babesia spp. infection in O.cuniculus in the literature. In this study, anti-B. caballi antibodies have been detected in $9.7 \%$ of O.cuniculus using IFAT in serum samples. B. caballi, the causative agent of equine piroplasmosis has never been reported in rabbits. However, as it has been shown in previous studies, cross reaction between different Babesia spp., including B. caballi, cannot be excluded [28,29]. Zoonotic Babesia spp have been detected in other wild rabbit species. Interestingly, B. divergens DNA was detected in $16 \%$ of the Eastern cottontail rabbits (S. floridanus) sampled in Massachusetts [79]. B. divergens is vectored by Ixodes dentatus, a rabbit and bird feeding tick that may also feed on human. Molecular evidence indicated that the same Babesia spp. was identified in human cases in Missouri and Kentucky [79], suggesting that this species may be a reservoir hosts for the parasite. A single eastern cottontail rabbit was molecularly positive for Babesia sp. MO1 in Tennessee, while in the same study, $25 \%$ of the rabbits were found seropositive for B. odocoilei, $38 \%$ for Babesia sp. MO1 and 25\% for both B. odocoilei and Babesia sp. MO1, suggesting possible cross-reaction or, potentially, co-infection [80]. In Greece, Babesia spp. has been serologically, cytologically and/or molecularly identified in horses [81], ruminants [82,83] and dogs [75].

The presence of antibodies in the aqueous humor can be attributed to either an increased permeability of the blood aqueous barrier or to the local antibody production, especially caused by microorganisms involved in the pathogenesis of uveitis [84,85]. Moreover, the correlation between the protein concentration of aqueous fluid and plasma depends on the molecular weight of the protein and it is reported to be stronger for small proteins [86]. 
In the present study, we report for the first time the detection of antibodies against L. infantum, T. gondii, A. phagocytophilum and B. caballi in the aqueous humor of naturally infected wild rabbits. The presence of T. gondii antibodies in aqueous humor of rabbits was shown previously in an experimental study conducted to investigate the local production of IgG in ocular toxoplasmosis using a rabbit model of the disease. This study suggested that specific antibodies were detectable and persistent in aqueous humor and serum for at least 100 days [38]. Another study in rabbits experimentally infected with Toxocara canis, showed that anti-T. canis IgG levels in the aqueous humor were well correlated with the severity of intraocular inflammation. The authors suggested that the discordance between serum IgG and aqueous humor IgG levels cannot be explained solely by the diffusion of parasite-specific antibodies through a leaky blood-aqueous barrier but also by the local antibody production in the eye [33]. Concerning the anti-Leishmania IgG detection in aqueous humor, previous studies showed the presence of higher IgG levels in ocular sampled of dogs with uveitis despite the level of antibody in the serum or even in the absence of anti-Leishmania IgG in the serum [37,87]. In the latter study, positive results were obtained from the aqueous humor and plasma samples in $72 \%$ of the dogs and a $C$ value greater than one was observed in $56 \%$ of the studied animals. The authors suggested that the anti-Leishmania antibody levels in plasma were superior to those found in the aqueous humor [87]. In the present study, lower IgG levels were found in the aqueous humor of naturally infected rabbits compared to serum, for all the pathogens examined, especially when the same cut off value was used in both biological samples.

Despite the uncertainty of the origin of the antibodies in the present study, as well as in previous studies, the assessment of the diagnostic utility of the ocular fluid revealed that the detection of antibodies in aqueous humor presents high specificity $(100 \%)$ but low sensitivity compared to the antibody detection in serum suggesting that aqueous humor could be successfully used in epidemiological studies to confirm exposure at population level but has little diagnostic value at the individual level. In the present study, the diagnostic utility of the ocular fluid was assessed by sensitivity and specificity while the positive and negative predictive value were not reported, since they depend on the prevalence of the disease which for the pathogens tested in this study, was unknown [54]. To the contrary, both PLR and NLR were calculated which are independent of disease prevalence and invariable among different populations or settings. The PLR, however, could be calculated only when antibodies against $A$. phagocytophilum and B. caballi were detected in the ocular fluid with a cut off value of 1:10, whereas in all other cases, this was not possible because the $100 \%$ specificity resulted in the denominator of the equation to be zero. Based on the PLR value, which in all cases was indicative of good performance, antibodies are likely to be detected in the ocular fluid for a seropositive animal. To the contrary, the NLR values are indicative of poor performance, while the lowest (best) NLR value was calculated for the detection of antibodies against $L$. infantum using a cut off value 1:10.

Moreover, the agreement between the results of antibodies in both fluids were fair to moderate and it was improved when the 1:10 cut off value was used in the aqueous humor. However, further studies in a larger number of samples are needed for the establishment of the optimal cut-off value to assure the best combination of specificity and sensitivity values in aqueous humor. Additional studies are also required to determine the real prevalence of these pathogens and the role of wild rabbits in their epidemiology such as molecular studies for the detection of the pathogens in organ/meat samples.

\section{Conclusions}

Exposure of wild rabbits to L. infantum, T. gondii, A. phagocytophilum and B. caballi in Greece was evidenced by the detection of antibodies against all the above-mentioned pathogens in serum as well as in aqueous humor. The lower IgG levels in ocular fluid for all the pathogens included in the study compared to serum, is suggestive of employing a low cut off value to increase sensitivity of the antibody detection in the aqueous humor. This 
study showed that negative results in the ocular fluid do not preclude the possibility of the presence of antibodies in the serum samples of wild rabbits. On the other hand, antibody detection against L. infantum, T. gondii, A. phagocytophilum and B. caballi in the ocular fluid almost certainly indicate the presence of antibodies against each pathogen in serum suggesting that aqueous humor could be successfully used in epidemiological studies to confirm exposure at population level but has little diagnostic value at the individual level.

Supplementary Materials: The following are available online at https: / www.mdpi.com/article / 10.3390/microorganisms9122616/s1, Table S1: Results of antibody detection against L. infantum, T. gondii, A. phagocytophilum and B. caballi in wild rabbits, in serum and in aqueous humor at individual level using different cut-off points.

Author Contributions: L.V.A. and E.G.K.; methodology, V.G.P.; software, S.G.B. and M.G.B.; validation, L.V.A., V.G.P.; formal analysis, C.N.T.; investigation, E.G.K.; resources, L.V.A. and S.G.B.; data curation, S.G.B. and M.G.B.; writing—original draft preparation, E.G.K. and C.N.T.; writing-review and editing, L.V.A., V.G.P., C.N.T., E.G.K., M.G.B. and S.G.B.; visualization, E.G.K. and C.N.T.; supervision, L.V.A. and V.G.P.; project administration, L.V.A.; funding acquisition, L.V.A., V.G.P. and S.G.B. All authors have read and agreed to the published version of the manuscript.

Funding: This research received no external funding.

Institutional Review Board Statement: Ethical review and approval were waived for this study, due to the collection of samples from already dead animals. All procedures contributing to this work met the ethical standards of the relevant national and European regulations on the care and use of animals (Directive 2010/63/EC).

Informed Consent Statement: Not applicable.

Data Availability Statement: The data presented in this study are available on request from the corresponding author. The data are not publicly available due to further processing for other studies.

Conflicts of Interest: The authors declare no conflict of interest.

\section{References}

1. Ferrand, N. Inferring the Evolutionary History of the European Rabbit (Oryctolagus cuniculus) from Molecular Markers. In Lagomorph Biology; Alves, P.C., Ferrand, N.K.H., Eds.; Springer: Berlin/Heidelberg, Germany, 2008; pp. 47-63.

2. Martín-Sánchez, J.; Torres-Medina, N.; Morillas-Márquez, F.; Corpas-López, V.; Díaz-Sáez, V. Role of wild rabbits as reservoirs of leishmaniasis in a non-epidemic Mediterranean hot spot in Spain. Acta Trop. 2021, 222, 106036. [CrossRef] [PubMed]

3. McKenny, L.; O’Handley, R.; Kovaliski, J.; Mutze, G.; Peacock, D.; Lanyon, S. Evidence of infection with Toxoplasma gondii and Neospora caninum in South Australia: Using wild rabbits as a sentinel species. Aust. Vet. J. 2020, 98, 380-387. [CrossRef]

4. Solano-Gallego, L.; Koutinas, A.; Miró, G.; Cardoso, L.; Pennisi, M.G.; Ferrer, L.; Bourdeau, P.; Oliva, G.; Baneth, G. Directions for the diagnosis, clinical staging, treatment and prevention of canine leishmaniosis. Vet. Parasitol. 2009, 165, 1-18. [CrossRef] [PubMed]

5. Quinnell, R.J.; Courtenay, O. Transmission, reservoir hosts and control of zoonotic visceral leishmaniasis. Parasitology 2009, 136, 1915-1934. [CrossRef]

6. Millán, J.; Ferroglio, E.; Solano-Gallego, L.J.P.R. Role of wildlife in the epidemiology of Leishmania infantum infection in Europe. Parasitol. Res. 2014, 113, 2005-2014. [CrossRef]

7. Molina, R.; Jiménez, M.I.; Cruz, I.; Iriso, A.; Martín-Martín, I.; Sevillano, O.; Melero, S.; Bernal, J. The hare (Lepus granatensis) as potential sylvatic reservoir of Leishmania infantum in Spain. Vet. Parasitol. 2012, 190, 268-271. [CrossRef] [PubMed]

8. Jiménez, M.; González, E.; Iriso, A.; Marco, E.; Alegret, A.; Fúster, F.; Molina, R. Detection of Leishmania infantum and identification of blood meals in Phlebotomus perniciosus from a focus of human leishmaniasis in Madrid, Spain. Parasitol. Res. 2013, 112, 2453-2459. [CrossRef] [PubMed]

9. Ruiz-Fons, F.; Ferroglio, E.; Gortázar, C. Leishmania infantum in free-ranging hares, Spain, 2004-2010. Eurosurveillance 2013, 18, 20541. [CrossRef] [PubMed]

10. Tsokana, C.N.; Sokos, C.K.; Giannakopoulos, A.; Mamuris, Z.; Birtsas, P.; Papaspyropoulos, K.; Valiakos, G.; Spyrou, V.; Lefkaditis, M.; Chatzopoulos, D.C.; et al. First evidence of Leishmania infection in European brown hare (Lepus europaeus) in Greece: GIS analysis and phylogenetic position within the Leishmania spp. Parasitol. Res. 2015, 115, 313-321. [CrossRef] [PubMed]

11. Rocchigiani, G.; Ebani, V.V.; Nardoni, S.; Bertelloni, F.; Bascherini, A.; Leoni, A.; Mancianti, F.; Poli, A. Molecular survey on the occurrence of arthropod-borne pathogens in wild brown hares (Lepus europaeus) from Central Italy. Infect. Genet. Evol. J. Mol. Epidemiol. Evol. Genet. Infect. Dis. 2018, 59, 142-147. [CrossRef] [PubMed] 
12. Hoverman, J.T.; Searle, C.L. Behavioural influences on disease risk: Implications for conservation and management. Anim. Behav. 2016, 120, 263-271. [CrossRef]

13. Tomassone, L.; Berriatua, E.; De Sousa, R.; Duscher, G.G.; Mihalca, A.D.; Silaghi, C.; Sprong, H.; Zintl, A. Neglected vector-borne zoonoses in Europe: Into the wild. Vet. Parasitol. 2018, 251, 17-26. [CrossRef] [PubMed]

14. Dubey, J.P. Toxoplasmosis of Animals and Humans, 3rd ed.; CRC Press/Taylor \& Francis: Boca Raton, FL, USA, 2021.

15. Almeria, S.; Dubey, J.P. Foodborne transmission of Toxoplasma gondii infection in the last decade. An overview. Res. Vet. Sci. 2021, 135, 371-385. [CrossRef] [PubMed]

16. Almeria, S.; Murata, F.H.A.; Cerqueira-Cézar, C.K.; Kwok, O.C.H.; Shipley, A.; Dubey, J.P. Epidemiological and Public Health Significance of Toxoplasma gondii Infection in Wild Rabbits and Hares: 2010-2020. Microorganisms 2021, 9, 597. [CrossRef]

17. do Nascimento, L.C.; Pena, H.F.J.; Leite Filho, R.V.; Argenta, F.F.; Alves, B.F.; Oliveira, S.; Gennari, S.M.; Driemeier, D. Rare case of acute toxoplasmosis in a domestic rabbit (Oryctolagus cuniculus) in Brazil associated with the type BrIII Brazilian clonal lineage of Toxoplasma gondii. Parasitol. Res. 2017, 116, 2873-2876. [CrossRef]

18. Ebani, V.V.; Poli, A.; Rocchigiani, G.; Bertelloni, F.; Nardoni, S.; Papini, R.A.; Mancianti, F. Serological survey on some pathogens in wild brown hares (Lepus europaeus) in Central Italy. Asian Pac. J. Trop. Med. 2016, 9, 465-469. [CrossRef] [PubMed]

19. Goethert, H.K.; Telford, S.R., 3rd. Enzootic transmission of Anaplasma bovis in Nantucket cottontail rabbits. J. Clin. Microbiol. 2003, 41, 3744-3747. [CrossRef]

20. Yabsley, M.J.; Romines, J.; Nettles, V.F. Detection of Babesia and Anaplasma species in rabbits from Texas and Georgia, USA. Vector Borne Zoonotic Dis. 2006, 6, 7-13. [CrossRef] [PubMed]

21. Zhan, L.; Chu, C.Y.; Zuo, S.Q.; Wu, X.M.; Dumler, J.S.; Jia, N.; Jiang, B.G.; Yang, H.; Cao, W.C. Anaplasma phagocytophilum and Borrelia burgdorferi in rabbits from southeastern China. Vet. Parasitol. 2009, 162, 354-356. [CrossRef] [PubMed]

22. Schmitz, K.M.; Foley, J.E.; Kasten, R.W.; Chomel, B.B.; Larsen, R.S. Prevalence of Vector-borne Bacterial Pathogens in Riparian Brush Rabbits (Sylvilagus bachmani riparius) and their Ticks. J. Wildl. Dis. 2014, 50, 369-373. [CrossRef] [PubMed]

23. Homer, M.J.; Aguilar-Delfin, I.; Telford, S.R., 3rd; Krause, P.J.; Persing, D.H. Babesiosis. Clin. Microbiol. Rev. 2000, 13, 451-469. [CrossRef]

24. Kjemtrup, A.M.; Thomford, J.; Robinson, T.; Conrad, P.A. Phylogenetic relationships of human and wildlife piroplasm isolates in the western United States inferred from the $18 \mathrm{~S}$ nuclear small subunit RNA gene. Parasitology 2000, 120, 487-493. [CrossRef] [PubMed]

25. Florin-Christensen, M.; Schnittger, L. Piroplasmids and ticks: A long-lasting intimate relationship. Front. Biosci. 2009, 14, 3064-3073. [CrossRef] [PubMed]

26. Gray, J.; Zintl, A.; Hildebrandt, A.; Hunfeld, K.-P.; Weiss, L. Zoonotic babesiosis Overview of the disease and novel aspects of pathogen identity. Ticks Tick-Borne Dis. 2010, 1, 3-10. [CrossRef] [PubMed]

27. Young, K.M.; Corrin, T.; Wilhelm, B.; Uhland, C.; Greig, J.; Mascarenhas, M.; Waddell, L.A. Zoonotic Babesia: A scoping review of the global evidence. PLoS ONE 2019, 14, e0226781. [CrossRef] [PubMed]

28. Alvarez, J.A.; Rojas, C.; Figueroa, J.V. Diagnostic Tools for the Identification of Babesia sp. in Persistently Infected Cattle. Pathogens 2019, 8, 143. [CrossRef]

29. Baldani, C.; Machado, R.; Raso, T.; Pinto, A. Serodiagnosis of Babesia equi in horses submitted to exercise stress. Pesqui. Vet. Bras.-CBPA 2007, 27, 179-183. [CrossRef]

30. Curry, P.S.; Elkin, B.T.; Campbell, M.; Nielsen, K.; Hutchins, W.; Ribble, C.; Kutz, S.J. Filter-paper blood samples for ELISA detection of Brucella antibodies in caribou. J. Wildl. Dis. 2011, 47, 12-20. [CrossRef] [PubMed]

31. Woodford, M.H. Post-Mortem Procedures for Wildlife Veterinarians and Field Biologists; Office International des Epizooties: Paris, France, 1999.

32. Sarran, D.; Greig, D.; Rios, C.; Zabka, T.; Gulland, F. Evaluation of Aqueous Humor as a Surrogate for Serum Biochemistry in California Sea Lions (Zalophus californianus). Aquat. Mamm. 2008, 34, 157. [CrossRef]

33. Akiyama, T.; Ohta, N. Parasite-specific antibody profile in the aqueous humor of rabbits with ocular toxocariasis. Parasitol. Int. 2010, 59, 112-120. [CrossRef] [PubMed]

34. Aston, E.J.; Mayor, P.; Bowman, D.D.; Mohammed, H.O.; Liotta, J.L.; Kwok, O.; Dubey, J.P. Use of filter papers to determine seroprevalence of Toxoplasma gondii among hunted ungulates in remote Peruvian Amazon. Int. J. Parasitol. Parasites Wildl. 2014, 3, 15-19. [CrossRef] [PubMed]

35. Dubay, S.; Rosenstock, S.; Stallknecht, D.; Devos, J. Determining Prevalence of Bluetongue and Epizootic Hemorrhagic Disease Viruses in Mule Deer in Arizona (USA) Using Whole Blood Dried on Paper Strips Compared to Serum Analyses. J. Wildl. Dis. 2006, 42, 159-163. [CrossRef] [PubMed]

36. Elmore, S.A.; Huyvaert, K.P.; Bailey, L.L.; Milhous, J.; Alisauskas, R.T.; Gajadhar, A.A.; Jenkins, E.J. Toxoplasma gondii exposure in arctic-nesting geese: A multi-state occupancy framework and comparison of serological assays. Int. J. Parasitol. Parasites Wildl. 2014, 3, 147-153. [CrossRef]

37. García-Alonso, M.; Blanco, A.; Reina, D.; Serrano, F.J.; Alonso, C.; Nieto, C.G. Immunopathology of the uveitis in canine leishmaniasis. Parasite Immunol. 1996, 18, 617-623. [CrossRef] [PubMed]

38. Garweg, J.G.; Boehnke, M. The antibody response in experimental ocular toxoplasmosis. Graefes Arch. Clin. Exp. Ophthalmol. 2006, 244, 1668-1679. [CrossRef] 
39. Jakubek, E.B.; Mattsson, R.; Mörner, T.; Mattsson, J.G.; Gavier-Widén, D. Potential application of serological tests on fluids from carcasses: Detection of antibodies against Toxoplasma gondii and Sarcoptes scabiei in red foxes (Vulpes vulpes). Acta Vet. Scand. 2012, 54, 13. [CrossRef]

40. Athanasiou, L.V.; Christodoulopoulos, G.; Polizopoulou, Z.S.; Kalaitzakis, E.; Papadakis, S.M.; Karatzia, M.A.; Katsogiannou, E.G.; Katsoulos, P.D. Post mortem aqueous humor analysis in sheep as index of ante mortem serum biochemistry profile. Small Rumin. Res. 2018, 159, 52-55. [CrossRef]

41. Chen, K.; Li, X.; Wang, D.; Ma, Y.; Chen, B.; Wang, Q.; Ma, J.; Guan, M. The diagnostic value of IL-10 and IL-6 level in vitreous fluid and aqueous humor for vitreoretinal lymphoma. Clin. Chim. Acta Int. J. Clin. Chem. 2021, 515, 21-26. [CrossRef] [PubMed]

42. Xu, L.; Kim, M.E.; Polski, A.; Prabakar, R.K.; Shen, L.; Peng, C.-C.; Reid, M.; Chevez-Barrios, P.; Kim, J.; Kuhn, P.; et al. Establishing Clinical Utility of ctDNA Analysis for Diagnosis, Prognosis, and Treatment Monitoring of Retinoblastoma: The Aqueous Humor Liquid Biopsy. Cancers 2021, 13, 1282. [CrossRef] [PubMed]

43. Felten, S.; Matiasek, K.; Gruendl, S.; Sangl, L.; Hartmann, K. Utility of an immunocytochemical assay using aqueous humor in the diagnosis of feline infectious peritonitis. Vet. Ophthalmol. 2018, 21, 27-34. [CrossRef]

44. Powell, C.C.; McInnis, C.L.; Fontenelle, J.P.; Lappin, M.R. Bartonella species, feline herpesvirus-1, and Toxoplasma gondii PCR assay results from blood and aqueous humor samples from 104 cats with naturally occurring endogenous uveitis. J. Feline Med. Surg. 2010, 12, 923-928. [CrossRef]

45. Wiggans, K.T.; Vernau, W.; Lappin, M.R.; Thomasy, S.M.; Maggs, D.J. Diagnostic utility of aqueocentesis and aqueous humor analysis in dogs and cats with anterior uveitis. Vet. Ophthalmol. 2014, 17, 212-220. [CrossRef]

46. Tsakmakidis, I.; Pavlou, C.; Tamvakis, A.; Papadopoulos, T.; Christodoulou, V.; Angelopoulou, K.; Dovas, C.I.; Antoniou, M.; Anastasakis, C.; Diakou, A. Leishmania infection in lagomorphs and minks in Greece. Vet. Parasitol. Reg. Stud. Rep. 2019, 16, 100279. [CrossRef] [PubMed]

47. Vasios, G.K.; Antoniadis, I.; Zevgolis, Y.; Giaginis, G.; Troumbis, A.Y. Turning a Problem into an Opportunity Through Tourism and Marketing: The Case of Wild Rabbits in Lemnos Island, Greece. In Strategic Innovative Marketing and Tourism; Kavoura, A., Kefallonitis, E., Theodoridis, P., Eds.; Springer: Berlin/Heidelberg, Germany, 2020; pp. 677-686.

48. ELGA. Compensation Statistical Data for 2007. Available online: http:/ / www.elga.gr/index.php?option=com_phocadownload\& view $=$ category\&id=16\&Itemid=103 (accessed on 10 November 2021).

49. Hadjigeorgiou, I.; Chatzigrorgiou, T.; Kosmas, C.; Kairis, O. Report on Lemnos Wild Rabbit Population; Agricultural University of Athens: Athens, Greece, 2018.

50. Ministerial. Decision HMEE/DFM 71082/539/2019 (GG3137/B/6-8-2019): Hunting Arrangements for the Hunting Season 2019-2020. Available online: https:/ / dasarxeio.com/wp-content/uploads/2019/08/71082_539_2019.pdf (accessed on 10 November 2021).

51. García, N.; Moreno, I.; Alvarez, J.; de la Cruz, M.L.; Navarro, A.; Pérez-Sancho, M.; García-Seco, T.; Rodríguez-Bertos, A.; Conty, M.L.; Toraño, A.; et al. Evidence of Leishmania infantum infection in rabbits (Oryctolagus cuniculus) in a natural area in Madrid, Spain. BioMed Res. Int. 2014, 2014, 318254. [CrossRef]

52. Almería, S.; Calvete, C.; Pagés, A.; Gauss, C.; Dubey, J.P. Factors affecting the seroprevalence of Toxoplasma gondii infection in wild rabbits (Oryctolagus cuniculus) from Spain. Vet. Parasitol. 2004, 123, 265-270. [CrossRef]

53. Varloud, M.; Liebenberg, J.; Fourie, J. Early Babesia canis transmission in dogs within $24 \mathrm{~h}$ and $8 \mathrm{~h}$ of infestation with infected pre-activated male Dermacentor reticulatus ticks. Parasites Vectors 2018, 11, 41. [CrossRef]

54. Gardner, I.A.; Greiner, M. Receiver-operating characteristic curves and likelihood ratios: Improvements over traditional methods for the evaluation and application of veterinary clinical pathology tests. Vet. Clin. Pathol. 2006, 35, 8-17. [CrossRef] [PubMed]

55. McHugh, M.L. Interrater reliability: The kappa statistic. Biochem. Med. 2012, 22, 276-282. [CrossRef]

56. Watson, P.F.; Petrie, A. Method agreement analysis: A review of correct methodology. Theriogenology 2010, 73, 1167-1179. [CrossRef] [PubMed]

57. Lopez-Martinez, N. The Lagomorph Fossil Record and the Origin of the European Rabbit. In Lagomorph Biology; Alves, P.C., Ferrand, N., Hackländer, K., Eds.; Springer: Berlin/Heidelberg, Germany, 2008; pp. 27-46.

58. Athanasiou, L.V.; Kontos, V.I.; Saridomichelakis, M.N.; Rallis, T.S.; Diakou, A. A cross-sectional sero-epidemiological study of canine leishmaniasis in Greek mainland. Acta Trop. 2012, 122, 291-295. [CrossRef]

59. Symeonidou, I.; Angelou, A.; Theodoridis, A.; Sioutas, G.; Papadopoulos, E. Canine Leishmaniosis in Greece: An Updated Countrywide Serological Study and Associated Risk Factors. Pathogens 2021, 10, 1129. [CrossRef] [PubMed]

60. Chitimia, L.; Muñoz-García, C.I.; Sánchez-Velasco, D.; Lizana, V.; Del Río, L.; Murcia, L.; Fisa, R.; Riera, C.; Giménez-Font, P.; Jiménez-Montalbán, P.; et al. Cryptic Leishmaniosis by Leishmania infantum, a feature of canines only? A study of natural infection in wild rabbits, humans and dogs in southeastern Spain. Vet. Parasitol. 2011, 181, 12-16. [CrossRef] [PubMed]

61. Díaz-Sáez, V.; Merino-Espinosa, G.; Morales-Yuste, M.; Corpas-López, V.; Pratlong, F.; Morillas-Márquez, F.; Martín-Sánchez, J. High rates of Leishmania infantum and Trypanosoma nabiasi infection in wild rabbits (Oryctolagus cuniculus) in sympatric and syntrophic conditions in an endemic canine leishmaniasis area: Epidemiological consequences. Vet. Parasitol. 2014, 202, 119-127. [CrossRef] [PubMed]

62. Moreno, I.; Álvarez, J.; García, N.; de la Fuente, S.; Martínez, I.; Marino, E.; Toraño, A.; Goyache, J.; Vilas, F.; Domínguez, L.; et al. Detection of anti-Leishmania infantum antibodies in sylvatic lagomorphs from an epidemic area of Madrid using the indirect immunofluorescence antibody test. Vet. Parasitol. 2014, 199, 264-267. [CrossRef] 
63. Ortega-García, M.V.; Salguero, F.J.; Rodríguez-Bertos, A.; Moreno, I.; García, N.; García-Seco, T.; Luz Torre, G.; Domínguez, L.; Domínguez, M. A pathological study of Leishmania infantum natural infection in European rabbits (Oryctolagus cuniculus) and Iberian hares (Lepus granatensis). Transbound. Emerg. Dis. 2019, 66, 2474-2481. [CrossRef]

64. Abbate, J.M.; Arfuso, F.; Napoli, E.; Gaglio, G.; Giannetto, S.; Latrofa, M.S.; Otranto, D.; Brianti, E. Leishmania infantum in wild animals in endemic areas of southern Italy. Comp. Immunol. Microbiol. Infect. Dis. 2019, 67, 101374. [CrossRef] [PubMed]

65. Ortega, M.V.; Moreno, I.; Domínguez, M.; de la Cruz, M.L.; Martín, A.B.; Rodríguez-Bertos, A.; López, R.; Navarro, A.; González, S.; Mazariegos, M.; et al. Application of a specific quantitative real-time PCR (qPCR) to identify Leishmania infantum DNA in spleen, skin and hair samples of wild Leporidae. Vet. Parasitol. 2017, 243, 92-99. [CrossRef] [PubMed]

66. Risueño, J.; Ortuño, M.; Pérez-Cutillas, P.; Goyena, E.; Maia, C.; Cortes, S.; Campino, L.; Bernal, L.J.; Muñoz, C.; Arcenillas, I.; et al. Epidemiological and genetic studies suggest a common Leishmania infantum transmission cycle in wildlife, dogs and humans associated to vector abundance in Southeast Spain. Vet. Parasitol. 2018, 259, 61-67. [CrossRef] [PubMed]

67. Dubey, J.P. Toxoplasmosis of Animals and Humans, 2nd ed.; CRC Press/Taylor \& Francis: Boca Raton, FL, USA, 2010.

68. Salman, D.; Oohashi, E.; Mohamed, A.E.A.; Abd El-Mottelib, A.E.-R.; Okada, T.; Igarashi, M. Seroprevalences of Toxoplasma gondii and Neospora caninum in pet rabbits in Japan. J. Vet. Med. Sci. 2014, 76, 855-862. [CrossRef]

69. Harfoush, M.; Tahoon Ael, N. Seroprevalence of Toxoplasma gondii antibodies in domestic ducks, free-range chickens, turkeys and rabbits in Kafr El-Sheikh Governorate Egypt. J. Egypt. Soc. Parasitol. 2010, 40, 295-302.

70. Mason, S.; Dubey, J.P.; Smith, J.E.; Boag, B. Toxoplasma gondii coinfection with diseases and parasites in wild rabbits in Scotland. Parasitology 2015, 142, 1415-1421. [CrossRef] [PubMed]

71. Waap, H.; Nunes, T.; Vaz, Y.; Leitão, A. Serological survey of Toxoplasma gondii and Besnoitia besnoiti in a wildlife conservation area in southern Portugal. Vet. Parasitol. Reg. Stud. Rep. 2016, 3-4, 7-12. [CrossRef] [PubMed]

72. Coelho, C.; Vieira-Pinto, M.; Vilares, A.; Gargaté, M.J.; Rodrigues, M.; Cardoso, L.; Lopes, A.P. PCR Detection of Toxoplasma gondii in European Wild Rabbit (Oryctolagus cuniculus) from Portugal. Microorganisms 2020, 8, 1926. [CrossRef]

73. Hughes, J.M.; Thomasson, D.; Craig, P.S.; Georgin, S.; Pickles, A.; Hide, G. Neospora caninum: Detection in wild rabbits and investigation of co-infection with Toxoplasma gondii by PCR analysis. Exp. Parasitol. 2008, 120, 255-260. [CrossRef]

74. Tsiodras, S.; Spanakis, N.; Spanakos, G.; Pervanidou, D.; Georgakopoulou, T.; Campos, E.; Petra, T.; Kanellopoulos, P.; Georgiadis, G.; Antalis, E.; et al. Fatal human anaplasmosis associated with macrophage activation syndrome in Greece and the Public Health response. J. Infect. Public Health 2017, 10, 819-823. [CrossRef] [PubMed]

75. Diakou, A.; Di Cesare, A.; Morelli, S.; Colombo, M.; Halos, L.; Simonato, G.; Tamvakis, A.; Beugnet, F.; Paoletti, B.; Traversa, D. Endoparasites and vector-borne pathogens in dogs from Greek islands: Pathogen distribution and zoonotic implications. PLoS Negl. Trop. Dis. 2019, 13, e0007003. [CrossRef] [PubMed]

76. Katsogiannou, E.G.; Katsoulos, P.D.; Christodoulopoulos, G.; Polizopoulou, Z.S.; Papadakis, S.M.; Kokkinaki, K.C.; Billinis, C.; Boutsini, S.; Stougiou, D.; Athanasiou, L.V. Quantitative and Morphological Blood Cell Findings Associated with the Presence of Antigen and/or Antibodies Against Anaplasma phagocytophilum in Sheep. Vector Borne Zoonotic Dis. 2021, 21, 321-329. [CrossRef]

77. Snellgrove, A.N.; Krapiunaya, I.; Ford, S.L.; Stanley, H.M.; Wickson, A.G.; Hartzer, K.L.; Levin, M.L. Vector competence of Rhipicephalus sanguineus sensu stricto for Anaplasma platys. Ticks Tick-Borne Dis. 2020, 11, 101517. [CrossRef]

78. Goethert, H.K.; Telford, S.R., 3rd. Enzootic transmission of the agent of human granulocytic ehrlichiosis among cottontail rabbits. Am. J. Trop. Med. Hyg. 2003, 68, 633-637. [CrossRef] [PubMed]

79. Goethert, H.K.; Telford, S.R., 3rd. Enzootic transmission of Babesia divergens among cottontail rabbits on Nantucket Island, Massachusetts. Am. J. Trop. Med. Hyg. 2003, 69, 455-460. [CrossRef] [PubMed]

80. Fritzen, C.; Mosites, E.; Applegate, R.D.; Telford, S.R., 3rd; Huang, J.; Yabsley, M.J.; Carpenter, L.R.; Dunn, J.R.; Moncayo, A.C. Environmental investigation following the first human case of babesiosis in Tennessee. J. Parasitol. 2014, 100, 106-109. [CrossRef]

81. Kouam, M.K.; Kantzoura, V.; Gajadhar, A.A.; Theis, J.H.; Papadopoulos, E.; Theodoropoulos, G. Seroprevalence of equine piroplasms and host-related factors associated with infection in Greece. Vet. Parasitol. 2010, 169, 273-278. [CrossRef] [PubMed]

82. Papadopoulos, B.; Brossard, M.; Perié, N.M. Piroplasms of domestic animals in the Macedonia region of Greece 3. Piroplasms of small ruminants. Vet. Parasitol. 1996, 63, 67-74. [CrossRef]

83. Papadopoulos, B.; Brossard, M.; Perié, N.M. Piroplasms of domestic animals in the Macedonia region of Greece 2. Piroplasms of cattle. Vet. Parasitol. 1996, 63, 57-66. [CrossRef]

84. Turunen, H.J.; Leinikki, P.O.; Saari, K.M. Demonstration of intraocular synthesis of immunoglobulin G toxoplasma antibodies for specific diagnosis of toxoplasmic chorioretinitis by enzyme immunoassay. J. Clin. Microbiol. 1983, 17, 988-992. [CrossRef] [PubMed]

85. Meunier, V.; Jourda, S.; Deville, M.; Guillot, J. Prevalence of anti-Toxoplasma gondii antibodies in serum and aqueous humor samples from cats with uveitis or systemic diseases in France. Vet. Parasitol. 2006, 138, 362-365. [CrossRef]

86. Ragg, S.; Key, M.; Rankin, F.; WuDunn, D. The Effect of Molecular Weight on Passage of Proteins Through the Blood-Aqueous Barrier. Investig. Ophthalmol. Vis. Sci. 2019, 60, 1461-1469. [CrossRef]

87. Brito, F.L.C.; Alves, L.C.; Maia, F.C.L.; Santos, E.S.C.; Laus, J.L.; Meunier, I. Ocular alterations in dogs naturally infected by Leishmania (Leishmania) chagasi. Arq. Bras. Med. Vet. Zootec. 2006, 58, 768-775. [CrossRef] 